\title{
IMPROVING STUDENTS' SPEAKING SKILLS THROUGH SOCIODRAMATIC PLAY AT THE SECOND GRADE STUDENTS OF SMA NEGERI 2 MAMUJU
}

\author{
Muhammad Ybnu Taufan \\ mybnutunm@gmail.com \\ Universitas Tomakaka, Indonesia
}

\begin{abstract}
This study aims at finding out the effectiveness of sociodramatic play in improving students' speaking skills. This study is quantitative research with Classroom Action Research (CAR) design. Data sources of the study were the second grade students of SMAN 2 Mamuju. The participants were taken through purposive random sampling technique. Data were collected by using observation, test and questionnaire. In this study, post- test was conducted in three cycles. The results of the study show that students had made some progress during the learning process. In pre-test, most of the students were having poor speaking skills with as many as $53 \%$ participants were in this category. However, there were significant improvements toward students' speaking skills with no more students with both very poor and poor speaking skills in third cycle. From the result of the tests, it can be concluded that sociodramatic play is useful to improve students", speaking skill. In addition, most of students feel interested and enjoy the learning process by having sociodramatic play in speaking class.
\end{abstract}

Keywords: sociodramatic play, speaking skills, improvements

\section{INTRODUCTION}

To make learners to possess good communicative skills is one of the challenges faced by the EFL teachers in English Language Teaching. The challenges might arise from many factors that inhibit students to speak English well. Shyness, lack of vocabulary and afraid of making mistakes in speaking English has been the major problems experienced by the Indonesian EFL learners (Nurlita: 2018). In addition, Nunan (1999) noted that many English learners are reluctant to speak and also unmotivated. Moreover, often, the strategies used by teachers are less interesting for students. Therefore, the use of an apropos strategy to improve communicative skills is urgently needed. Most importantly, students should have a positive attitude toward it (Kayi: 2006). Furthermore, Khameis (2006) states that in order to motivate students to speak and to encourage their participation in speaking class, teacher should focus on strategies that interesting and could capture their attention.

As a memorization of dialogues has long been introduced to improve students' communicative skills (Kayi: 2006), sociodramatic play became infallible to be adopted in speaking class. Sociodramatic play as a form of symbolic play where students pretend to take on a role of someone else, imitating actions and speech is simply a great means to encourage students' motivation and participation in speaking class. The effectiveness of this strategy is making the speaking class become more dynamic and enthusiastic. 


\section{LITERATURE OF REVIEW}

\section{A. Defining sociodramatic play}

Acccording to Smilansky (1968) sociodramatic play is a way for children to develop social and language skills, by creating imaginary world, characters, and scenarios, which related to the real world. According to Roestiyah (2010), sociodramatic play is an action where students dramatize behavior, gestures or expressions of a person's face in the social relationship between humans.

\section{B. The features of sociodramatic play}

According to Dinham \& Chalk (2018) Sociodramatic play usually involves learners:

1. Developing roles

2. Creating their own storyline

3. Making up their own spoken lines (dialogues)

4. Interacting with each other

5. Directing each other in play

\section{Adopting sociodramatic play in speaking class}

To adopt sociodramatic play in speaking class, Maimuna (2014) introduces several sequences of steps to apply this strategy in speaking class:

1. Teacher introduces sociodramatic play to the class.

2. The class then divided into several groups.

3. Teacher lets students to determine the themes and scenarios by themselves including the dialogues, situations, issues, events and background.

4. Students practicing the role playing

5. Teacher gives corrective feedback toward errors made by students after the dramatic plays are finish.

\section{Several related previous studies}

A study conducted by Susilawaty (2013) found that role play in drama could help students to understand oral language easily. In addition, it helps students' to improve their vocabulary, grammar, pronunciation and fluency. Furthermore, it could develop the teaching of speaking to a better direction. Stevia (2017) found that the student's learning outcomes through sociodrama were satisfying. The implementation of the sociodrama in learning conversational skills could improve students' grammar, vocabulary and pronunciation. Nehe (2018) found that the implementation of sociodrama help the students to practice speaking skills a lot and help them to improve their speaking skills from aspects of pronunciation, vocabulary, grammar and fluency. 


\section{METHOD}

This research employed quantitative research with Classroom Action Research (CAR) design. Cresswell (2004) noted that quantitative research is the process of collecting, analyzing, interpreting and writing the result of the study. As stated by Borg, Gall and Gall (1993: 391), one of the purpose of Classroom Action Research (CAR) is to help the practitioner identify problems and to seek solution in a systematic fashion. In this research, researcher tried to seek solution to improve students' speaking skills.

The research was conducted at SMAN 2 Mamuju where the second grade students were chosen as the participants of the research. In selecting the samples, the study employed purposive random sampling. 30 participants from class X1 MIA 1 were chosen as the sample where it was consisting of 12 male students and 18 female students. The data were collected through observation, speaking test and questionnaire. Pre-test conducted to obtain the students' prior-speaking skills. In speaking class, the researcher was adopting sociodramatic play. The students were asked to use their imagination to design their own storylines and spoken lines (dialogues), and then the students practiced the role play. After finish their role playing, corrective feedback was given toward the students' errors.

Post-tests were conducted in three cycles. In these tests, the researcher assessed how well the students in speaking English by asking some questions orally. An assessment criterion guideline has been provided to help researcher to assess the students' speaking skills. The speaking skill assessment components are including pronunciation, grammar, vocabulary, and fluency. Furthermore, to know the students' perception toward sociodramatic play in speaking class, a questionnaire has been made by the researcher.

\section{RESULT AND DISCUSSIONS}

\section{A. The students' speaking skills progress}

\section{STUDENTS' SPEAKING SKILLS IN PRE-TEST}

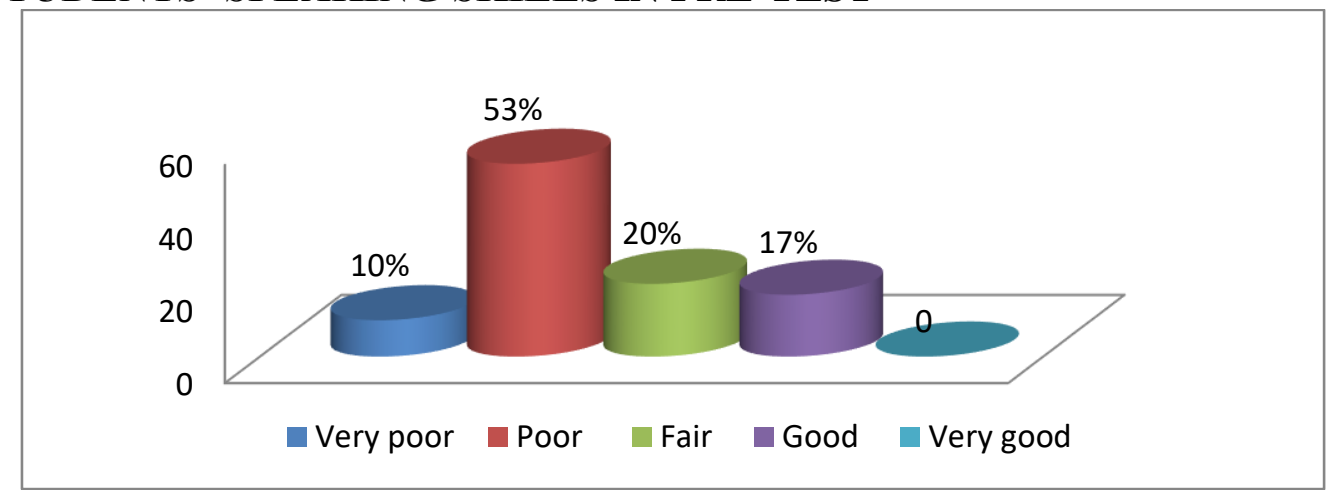

Above chart shows the students' speaking skills in pre-test. Pre-test was conducted to get the information about students' prior-speaking skills. It shows that most of the students were having poor speaking skills with 53\% students in this category. There were $10 \%$ of students having very poor speaking skills, $20 \%$ students having fair speaking 
skills and $17 \%$ of students were having good speaking skills. However, none of student was having very good speaking skills.

2. STUDENTS' SPEAKING SKILLS IMPROVEMENT IN CYCLE I,II, AND III



On the first post-test, students' speaking skills has improved quite significant. It can be seen from the result of data analysis that no more students were stay in very poor category. However, there were still $40 \%$ of students stays in poor category. Students with fair speaking skill category were increased to $27 \%$ and students with good speaking skill category were increased to $23 \%$. In this stage, students with very good skill were growing to $10 \%$.

On the second post-test, students' speaking skills has improved significantly. It can be seen from the data that students with poor category decreased to $20 \%$. While students with fair speaking skills dramatically increased to $40 \%$. Students with good speaking skills increased slightly to $27 \%$, similarly to students with very good speaking which increased slightly to $13 \%$.

On the third post-test, students' speaking skills was dramatically improved. It can be seen from the data that no more students possess both very poor and poor speaking skills. In this stage, students with very good speaking skills were increased slightly to $17 \%$, and students with fair speaking skills decreased to $33 \%$. However, students with good speaking skill were dramatically increased to $50 \%$. 


\section{B. The students' perception toward the sociodramatic play in speaking class}

Questionnaire had been distributed to students to obtain information about their attitude toward sociodramatic play. Here, students chose the answer based on what they feel about the sociodramatic play. The options were consisting of strongly agree (SA), agree, (A), disagree (D) and strongly disagree (SD).

\begin{tabular}{|c|l|c|c|c|c|}
\hline No. & \multicolumn{1}{|c|}{ Statements of questionnaire } & SA & A & D & SD \\
\hline 1. & $\begin{array}{l}\text { I feel interested in the use of sociodramatic } \\
\text { play in learning conversational skills }\end{array}$ & $90 \%$ & $10 \%$ & - & - \\
\hline 2. & $\begin{array}{l}\text { I enjoy having sociodramatic play with my } \\
\text { friends }\end{array}$ & $83 \%$ & $17 \%$ & - & - \\
\hline 3. & $\begin{array}{l}\text { Sociodramatic play effectively improves my } \\
\text { speaking skills }\end{array}$ & $87 \%$ & $13 \%$ & - & - \\
\hline 4. & $\begin{array}{l}\text { My fluency, pronunciation, and vocabulary } \\
\text { improved after having sociodramatic play }\end{array}$ & $90 \%$ & $10 \%$ & - & - \\
\hline 5. & $\begin{array}{l}\text { I feel not shy to speak English anymore after I } \\
\text { was having sociodramatic play }\end{array}$ & $80 \%$ & $20 \%$ & - & - \\
\hline 6. & $\begin{array}{l}\text { I feel optimistically that my English will be } \\
\text { more better after having sociodramatic play }\end{array}$ & $87 \%$ & $13 \%$ & - & - \\
\hline 7. & $\begin{array}{l}\text { I feel easy to speak English after I was having } \\
\text { the sociodramatic play }\end{array}$ & $80 \%$ & $20 \%$ & - & - \\
\hline 8. & $\begin{array}{l}\text { I feel confident in speaking after I was having } \\
\text { the sociodramatic play }\end{array}$ & $80 \%$ & $20 \%$ & - & - \\
\hline 9. & $\begin{array}{l}\text { I feel satisfy with my speaking progress and } \\
\text { expecting another sociodramatic play }\end{array}$ & $83 \%$ & $17 \%$ & - & - \\
\hline 10. & $\begin{array}{l}\text { My attitude toward English subject go } \\
\text { positive after I was having sociodramatic play }\end{array}$ & $87 \%$ & $13 \%$ & - & - \\
\hline
\end{tabular}

The table above indicates that most of students feel interested and enjoy the using of sociodramatic play in speaking class. As many studies had been conducted previously to improve students' speaking skills through conversational strategy, this research found the same thing where the implementation of sociodramatic play are successfully help the researcher in effort to improving the students' speaking skills. Moreover, learning conversational skills through sociodramatic play is more interesting for students.

\section{CONCLUSIONS, IMPLICATION, AND SUGGESTIONS}

The conclusion to this research is that students' speaking skills has made some progress through sociodramatic play. Sociodramatic play was supporting the teacher to improve the students' communicative skills. In addition, the students also show a positive attitude toward sociodramatic play in class.

Teaching speaking is not an easy thing to do. Therefore, the researcher suggests that 
in speaking class, teacher should adopt a motivating strategy to promote students' speaking skills. Teacher also should be able to create enthusiasm and enjoyment in learning process. In addition, teacher is expected to adopt Sociodramatic play as an alternative strategy in improving speaking skills. For students, in order to be successful in possessing good speaking skills, a good attitude toward the strategy applied in the speaking class is extremely required.

\section{REFERENCES}

Cresswell, J. W. 2004. Educational Research: Planning, Conducting, and Evaluating Quantitative and Qualitative Research. (3rd Edition).

Dewi, R. K. 2011. Improving students' speaking skills through dialogue. Journal of education and practice. (online). Retrieved on: April $10^{\text {th }} 2019$ from https://digilib.uns.ac.id.

Dinham, J. and Chalk, B. 2018. It's art play: young children belonging, being and becoming through the arts. Sydney, Australia: Oxford University Press.

Gall, J. P., Gall, M. D., and Borg, W. R. 2005. Applying Educational Research: A Practical Guide. ( $5^{\text {th }}$ Edition). Boston: Pearson Education.

Kameis, M. 2006. Using creative strategies to promote students' speaking skills. Journal of education and practice. (online). Retrieved on: April 12 $12^{\text {th }} 2019$ from https://pdfs.semanticscholar.org.

Kayi, H. 2006. Teaching speaking: activities to promote speaking in a second language. The internet TESL Journal, Vol. XII, No. 11.

Maimuna, M. 2014. Improving Students' Ability To Play Drama Through Role Playing Method at SMAN 1 Bonehau. (Unpublished thesis). Universitas Tomakaka, Indonesia.

Nehe, M.B. 2018. Using Sociodrama in EFL Speaking Class: Related To Students Achievement. International Journal of Linguistic, Literature and Culture. Vol. 4, No. 4.

Nunan, D. 1999. Second Language Teaching and Learning. Boston: Heinle \& Heinle Publisher.

Nurlita, R. 2018. Inhibiting factors affecting students' English speaking ability. Journal of education. (online). Retrieved on: May $1^{\text {st }}, 2019$ from https://repository.ar-raniry.ac.id.

Roestiyah, K. N. 2010. langkah-langkah bermain drama. Jakarta: Rineka Cipta

Smilansky, S. 1968. The effects of sociodramatic play on disadvantaged preschool children. New York, NY: John Wiley\& Sons

Stevia, M. I. 2017. The Use of Sociodrama Method in Speaking Skill. Journal of education (online). Retrieved on: June $26^{\text {th }}, 2019$ from https://jurnal-mahasiswa.unisri.ac.id.

Sulistiawaty, E. R. 2013. Improving Students Speaking Skill Using Drama at The Eleven Grade Students of Language Class of MAN Yogyakarta II in the Academic Year of 2012/2013. (online). Retrieved on: July $4^{\text {th }}, 2019$ from https://eprints.uny.ac.id. 